\title{
THE BALTIC CHAIN: A STUDY OF THE ORGANISATION FACETS OF LARGE-SCALE PROTEST FROM A MICRO-LEVEL PERSPECTIVE
}

\author{
Paula Christie
}

\begin{abstract}
Following the introduction of Gorbachev's policy of glasnost, details of the secret protocols contained within the Molotov-Ribbentrop Pact of 1939 were subsequently published. This led to widespread condemnation of the Soviet annexation of the three Baltic countries, which culminated in one of the largest-ever human chain protests. How was a protest spanning 671 kilometres and involving almost two million people across Lithuania, Latvia and Estonia organised and coordinated? Did particular variables impact upon individual levels of participant engagement and experience? This article engages with the experiences of those who were involved in the protest at a grass-roots level, and provides a nuanced picture of participant engagement often lacking within the dominant commemorative narrative of the protest.
\end{abstract}

\section{Introduction}

The Baltic countries of Lithuania, Latvia and Estonia were surrendered to Soviet influence under the secret protocols contained within the Molotov-Ribbentrop Pact of 1939, drawn up between Nazi Germany and the USSR. ${ }^{1}$ The annexation of the three Baltic countries was not internationally recognised, and in the wake of Gorbachev's policy of glasnost, the publication of the protocols in 1988 sparked a number of large-scale nationalist protests calling for national sovereignty to be restored. ${ }^{2}$ On 23 August 1989 these nationalist protests culminated in the formation of an unbroken human chain made up of approximately two million men, women and children, from Lithuania, Latvia and Estonia, which stretched

1 R.J. Misiunas, R. Taagepera, The Baltic States: Years of Dependence, 1940-1980 (London, 1983).

2 D.J. Smith, A. Pabriks, A. Purs, T. Lane, The Baltic States, Estonia, Latvia and Lithuania (London, 2002), p. 48. 
671 kilometres across the three Baltic countries. ${ }^{3}$ This chain was one of the earliest and largest human chain protests ever to have taken place.

Numerous publications and public events provide a commemorative overview of the protest, including insightful work by Eglitis and Ardava, who draw on the event as an example of the use of collective memory within power structures. Their 2012 study considers the various commemorations of the Baltic Chain protest, and the subsequent legitimisation 'of existing institutions and practices' resulting from the event. ${ }^{4}$ Despite such works, it has been established that almost 30 years after this remarkable event, little study has been undertaken to consider the organisational strategies employed from below. This article brings a fresh evaluation of the events leading up to and including 23 August 1989 by considering the organisational approaches employed from a micro-level perspective. By engaging with the experiences of those who were involved in the protest at a grass-roots level, a nuanced picture of the role of both formal and informal networks employed emerges. This bottom-up evaluation of the protest has additionally reflected on areas of conflict within the individual experience of engagement with the protest often lacking within the dominant commemorative narrative, which presents the protest as a homogeneously supported event. Initial informal discussions around the protests, stemming from recollections of those who took part, suggested that 'everyone knew' something was happening, and that there was a tacit understanding of where to go and how to mobilise. Given the absence of electronic communications and social media networks commonplace today, the question 'how did everyone know?' requires investigation. This work considers which networks were key drivers in coordinating the protest at a micro-level. Furthermore, with the protest spanning 671 kilometres and involving around two million people, this article examines whether particular variables impacted upon individual levels of participant engagement and experience. To address these questions, this work has focused upon three central areas. The first section of the article examines whether clearly defined network structures existed, and ascertains

${ }^{3}$ V. Landsbergis, Lithuania, Independent Again: The Autobiography of Vytautas Landsbergis (Cardiff, 2000), p. 151.

${ }^{4}$ D.S. Eglitis, L. Ardava, 'The Politics of Memory: Remembering the Baltic Way 20 Years after 1989’, Europe-Asia Studies, 64(6) (2012), pp. 1033-1059. 
the impact of both informal structures and the corruption of official or formal network structures on the organisation of the protest. Secondly, the role and the influence of the media are discussed, with attention given to the different media networks in existence during the period leading up to the protest. The final section considers instances in which conflict occurred as experienced by individuals and within communities, whilst simultaneously identifying areas in which differences, both social and ideological, were put aside in order to facilitate the protest.

Most authors argue that, prior to 1987, independent mass demonstrations were virtually unheard of within the Soviet Socialist Republics. ${ }^{5}$ A number of Soviet-era uprisings are explored in Kozlov's Mass Uprisings in the USSR; ${ }^{6}$ however, much of the existing literature on the mass protest movements in the Baltic States towards the end of the Soviet period presents mass demonstrations as being a progression of smaller protests. Eglitis notes that by the early and mid-1980s, small but significant islands of autonomy were appearing in the public sphere, and were predominantly culturally orientated with the resurgence of folk music, the emergence of local pop and rock bands, and exhibitions of protest art. ${ }^{7}$ Although the importance of the emergence of new community elites resulting from perestroika in the mid to late 1980s is much cited as a catalyst for the mobilisation of protesters, little or no information is given on the view from below, and on the tactics employed by protesters at a micro-level. Expanding on earlier works relating to the movement and dynamics of Baltic protests by Ulfeder and Muiznieks, this article considers the processes and practicalities of coordination within communities, and within those elite structures undergoing reform. The work questions whether changes in the political structure led to an expansion of opportunity for those previously seen as being outwith the political system, ${ }^{8}$ and assesses the ways in which any such opportunities evolved and were exploited. By extracting and examining the narratives of individuals involved in the protest, a

5 D.S. Eglitis, Imagining the Nation: History, Modernity, and Revolution in Latvia (University Park, PA, 2002), p. 22.

${ }^{6}$ V.A. Kozlov, E.M. MacKinnon, Mass Uprisings in the USSR: Protest and Rebellion in the post-Stalin Years (Armonk, NY, 2002).

${ }^{7}$ Eglitis, Imagining the Nation, p. 27.

8 D. Gorenbug, 'Ethnic Mobilization', Managing Ethnic Diversity in Russia, eds. O. Protsyk, B. Harzl (London, New York, 2013), p. 198. 
deeper and more nuanced reflection on varying levels of engagement across different locations is presented, and highlights areas of cohesion and conflict within individual participant experience.

The corruption of existing power structures is seen as a critical element in developing and facilitating large-scale protests as witnessed in the Baltic States and elsewhere in Eastern Europe. Many authors focus on the role played by actors who were able to take advantage of existing Soviet state structures which had weakened due to central government reform. Tilly and Tarrow discuss at length the ability to place 'social movements in the context of a much wider variety of power struggles' in the 2007 publication Contentious Politics, ${ }^{9}$ with Przeworski arguing that the Communist Party in Hungary was 'shattered not by its opponents but paradoxically- by the leadership' ${ }^{10}$ Existing Soviet structures and organisations had historically positioned the mass mobilisation of citizens and communities as a source of legitimacy for governance. Nationalists were able to use reforms to destabilise existing political elite alignments, and thus pursue 'control over public authority within a particular territory on behalf of members of their ethnic group'. ${ }^{11}$ With Eglitis noting that Soviet dominance was challenged by 'a marriage of macro and micro events', this work explores the rarely mentioned dynamics of the protest as viewed from below. ${ }^{12}$ By opting to focus on micro-level initiatives, this article relocates traditional commemorative reflections of the Baltic Chain which have, over the last 25 years, perhaps been dominated by successful leaders who have taken advantage of the political capital of the protest, thereby defining the preferred historical narrative currently reflected. ${ }^{13}$ This grass-roots analysis provides an alternative lens through which to challenge the existing mythical representations of the Baltic Chain protest, by incorporating the perspectives of non-elite participants, who, through their resistance to official Soviet indoctrination, instigated change.

This article draws upon observations made by several authors who suggest that mass protests were made possible under the Soviet

${ }^{9}$ C. Tilly, S. Tarrow, Contentious Politics (Colorado, 2007), p. xi.

${ }^{10}$ A. Przeworski, Democracy and the Market: Political and Economic Reforms in Eastern Europe and Latin America (Cambridge, New York, 1991), p. 56.

11 J. Ulfelder, 'Baltic Protest in the Gorbachev Era: Movement Content and Dynamics 1' The Global Review of Ethnopolitics 3(3-4) (2004), p. 23.

${ }^{12}$ Eglitis, Imagining the Nation, pp. 25-26.

13 Eglitis, Ardava, 'The Politics of Memory', p. 1035. 
system due to a sense of solidarity created by the necessary use of informal networks to create a system of barter and bribery. ${ }^{14}$ The system of barter or 'blat' employed by individuals living under Soviet rule was found to be an ambiguous term, and absent in the official discourse of the period. This is explained by Ledeneva, who argues that for many individuals, particular connotations of 'blat' are difficult to navigate, and may lead to embarrassment, coupled with fears that the term was 'un-Soviet'. ${ }^{15}$ With little discussion within existing literature on the Baltic Chain protest discussing the impact of informal bargaining strategies, this article investigates whether relationships of trust and trade established under the Soviet system influenced and supported the organisational mechanisms of the event.

A comprehensive analysis of postwar Lithuanian protest movements conducted by Petersen focuses on the growing impetus of rebellion in the region; however, it does not fully account for the enormous scale and success of the Baltic Chain protest. It is expressed that varying regions exhibit different patterns of rebellion, ${ }^{16}$ yet variations in participant and community experience are, again, notably absent within the dominant narrative. Rather, it has been found that much of the commemorative literature surrounding the protest positions the event as a homogeneous culmination of smaller-scale popular protests.

\section{Case and method}

This work is based upon an initial nine-month study on the Baltic Chain protest which, it is hoped, shall be expanded at a later date. A qualitative methods approach was adopted, which led to the generation of theories inductively as the research progressed. Empirical research was initially conducted in the UK, and included the use of archive-based materials, including extracts from the 'Homeland' newspaper published in 1989, and from some transcripts of Radio Free Europe broadcasts made prior to, during and after the Baltic

${ }^{14}$ S. Pfaff, Exit-voice Dynamics and the Collapse of East Germany: the Crisis of Leninism and the Revolution of 1989 (Durham, N.C., 2006); Eglitis, Imagining the Nation; A. V. Ledeneva, Russia's Economy of Favours: Blat, Networking and Informal Exchange (Cambridge, UK; New York, NY, 1998).

${ }^{15}$ Ledeneva, Russia's Economy of Favours, p. 13.

16 R.D. Petersen, Resistance and Rebellion: Lessons from Eastern Europe (Cambridge, New York, 2001), p. 8. 
Chain protest. These materials were available in English from the University of Glasgow library, and from the Glasgow Baltic Research Unit Archive, and were used to gain insights into the formulation of organisational strategies as disseminated from selected media sources. Secondary literature was also used to further examine protest movements within the Soviet Socialist Republics during the mid-1980s, and to frame the Baltic Chain protest within the context of these earlier events.

As this work focuses primarily on each participant's perception and understanding of experience, an interpretivist approach was adopted, with interviewees being chosen not necessarily as 'they are typical of a category, but for what they tell us about complex social processes'. ${ }^{17}$ Central to the project was new data obtained through fieldwork exploring the views and experiences of grassroots organisers, and of participants of the Baltic Chain protest of 1989. A series of twelve semi-structured interviews, reflecting an oral history approach, were conducted across various locations in Lithuania and Latvia, with participants selected from a range of age groups, backgrounds and locations. A caveat is provided in relation to the number of interviews conducted, and it would be intended to expand this sample size in future research. Participant age was a key consideration in participant recruitment, in order to explore any cross-generational differences within the participant experience. The age groups sampled included participants who were teenagers at the time of the protest, those aged between 30 and 45 during the protest, and those aged over 45. Details of age, gender and location of participants during the protest are provided; however, participants' names and names of smaller provincial towns have been omitted to protect participant anonymity. The countries included within this work were selected to identify any cross-border variance in organisational structures. Although the protest spread across the three Baltic countries of Lithuania, Latvia and Estonia, Lithuania and Latvia were specifically chosen in regard to the contrasting demographic resulting from Soviet-era migration. Additionally, the selection of these countries allowed for analysis of the differing role of religious influence upon organisational structures by contrasting the influence of the Lutheran Church in Latvia with the impact of

17 D. Della Porta, K. Keating, Approaches and Methodologies in the Social Sciences: A Pluralist Perspective (Cambridge, New York, 2008), p. 29. 
Catholic networks in Lithuania. Estonia was excluded due to time constraints with this work; however, it would be hoped that further research in this area could be conducted at a later stage.

\section{Informal networks and the corruption of official structures}

In considering the orchestration of a protest, it is important to ascertain which network structures influenced the event. Within the existing literature, the use of informal networks and the corruption of official structures are viewed as critical factors in the development of largescale public protests, yet are often disaggregated as separate entities. Within this work, the overlap and the space exploited between the various network strategies employed by non-elite actors to facilitate the protest have been examined. Ledeneva observes that 'the functioning of informal contacts and connections is predicated upon the structural characteristics of the Soviet system'. ${ }^{18}$ Additionally, it has been stated that mass protests were made possible under the Soviet system due to a sense of solidarity created by the necessary use of informal networks to create a system of barter and bribery. ${ }^{19}$ As identified by Ledeneva, 'blat' referring to a system of barter or exchange can be easily dismissed by individuals due an ambiguity in definition and negative connotation. Participant responses reflected the ambivalence associated with negotiations of 'blat', with many respondents being generally reticent on the direct impact of this network on the organisation of the protest. One respondent provided a response which was representative of many of the interviewees' reactions to questions on the use of this system. It was stated:

This for us is not important. I'm not sure why you ask about this blat. It was just normal life. I would not say that this was important (male participant G, Riga, Latvia; aged under 30 in 1989).

Yet there are clearly instances in which a system of informal relations and networks influenced events and facilitated protest. Earlier events that had been emerging within Latvia and Lithuania, such as the calendar demonstration in Latvia of 1987, and the Rock Marches of Lithuania during the same period utilised informal networks. One participant who was active in a Lithuanian punk band during the late 1980s recalled:

${ }^{18}$ Ledeneva, Russia's Economy of Favours, p. 36.

19 Pfaff, Exit-voice Dynamics and the Collapse of East Germany; Eglitis, Imagining the nation. 
You have to keep in mind that the class structure of the Soviet Union was completely different than in the Western world. In order to get instruments and so on you had to find some sort of organisation that could provide them for you. So we were playing in schools for example, or sometimes people's parents would be working in some place and we could ask for their equipment (male participant $\mathrm{J}$, Kaunas, Lithuania; aged under 30 in 1989).

Access to equipment used to film the Baltic Chain again benefitted from pre-existing relationships and informal structures of favour. Many journalists were particularly keen to shoot footage of the Baltic Chain spectacle both on the ground and from the air. Given that the Baltic States were still under Moscow's control, respondents were questioned as to which networks were responsible for organising the aircraft which were used to cover the event. An interview with a Latvian journalist who filmed sections of the protest explained the way in which informal networks utilised State organisations to afford the procurement of suitable aircraft. During a meeting of Latvian TV crews on the day of the protest, it emerged informal contacts could prove useful. It was stated that:

Someone knows someone who has links with the agrarian community, so I guess from there the helicopter was arranged. Somehow they had managed to hustle this thing up from an agrarian agency. These guys used to fly around looking at forest conditions and whatever (male participant H, Riga, Latvia; aged 30-45 in 1989).

As described by Ledeneva, 'favours of access became possible because they demanded no one's own resources and were perceived as "sharing", "helping out" friendly support'. ${ }^{20}$ Exchange or favour networks which had flourished as a result of the limited availability of hard currency under the command economy were relied upon in order to procure resources which were central to the organisation of the protest. Whilst informal networks established during the Soviet period were utilised by those organising the Baltic Chain protest, the corruption of official structures was also a tactic employed by non-elite activists to procure resources. This strategy mirrored earlier observations that 'in a totalitarian society, opposition movements can occur only when dissidents from within the Party gain temporary control of some organisations and associations normally under Party control, and use this basis for further mobilisation'. ${ }^{21}$ It was clearly expressed during the interviews conducted that local Party members

${ }^{20}$ Ledeneva, Russia's Economy of Favours, p. 35.

21 A. Oberschall, Social Conflict and Social Movements (Englewood Cliffs, N.J., 1973); Pfaff, Exit-voice Dynamics and the Collapse of East Germany, p. 6. 
utilised their positions to facilitate meetings and public events leading up to the Baltic Chain protest. One local activist explained that:

I was at this time the Director of the Sports Committee. I therefore had access to premises. Starting from then on, we would be posting invitations in local newspapers and also by asking around. Also I had access to rooms in tourist facilities because I was the Director of the Sports Committee (male participant I, provincial town, Latvia; aged 30-45 in 1989).

Well-known and well-placed activists were not only able to facilitate the practicalities of protest by obtaining the use of public spaces for meetings, but gave confidence in the local area that official structures could be corrupted for local advantage. A Lithuanian respondent was enthusiastic in observing that:

You are actually corrupting the official organisation. You are using all the official resources and networks, but you are using it for your own purpose (male participant J, Kaunas, Lithuania; aged 15-20 in 1989).

The opportunities resulting from informal networks and those official networks corrupted by non-elite activists were exploited by family groups, friendship networks and workplaces. For many, Soviet ideology had a profound effect on establishing close relationships between colleagues within workplaces, thereby allowing organisational networks to flourish. Workplace relationships were central in orchestrating the protest, with many companies allowing employees to take the day off to attend, or in some cases organising transport. An example of this is detailed in the following statement:

My mother worked at that time, and the question of organisation - I want to mention at the very beginning - that much of the organisation was made through workplaces. In Soviet times people would have quite a close relationship with the people of their workplace (female participant B, Kaunas, Lithuania; aged $30-45$ in 1989).

Many non-elite activists were playing multiple roles, both within officially sanctioned organisations and within informal network structures. This reflects the view of Pfaff, who argues that 'in a state that eliminates the public sphere and organisations independent of regime control, local networks nurture collective identities and solidarity, provide informal organisation and contacts, and offer information'. ${ }^{22}$ A key example of this was provided by a Lithuanian musician who described a contact as being:

22 Pfaff, Exit-voice Dynamics and the Collapse of East Germany, p. 76. 
... both secretary in charge of the Architects Union, and he was leader of his band, and he was also leader of the initiative group of Sajūdis. So actually he was the guy who kept all of those separate things together. He was actually the one who was using those corrupted official structures. He was using the resources of the Architect's Union (male participant J, Kaunas, Lithuania; aged 15-20 in 1989).

The participant, it should be noted, is perhaps referring to musician and architect Algirdas Kaušpedas, who was a member of the National Council of Sajūdis and not the initiative group of Sajūdis as stated, ${ }^{23}$ although the contact was not directly named by the participant during the interview.

Having established the close links between informal networks and the corruption of official structures, it was then reasonable to consider the practical methods employed by those using both systems to facilitate such a large-scale protest. It was found that the organisation of small local groups made organisational sense on a physical level. Baltic Popular Front movements had developed at an astounding pace, fed by workplace, family and friendship networks. ${ }^{24}$ In considering the practicalities of organising such a widespread nationalist movement which would ultimately galvanise into the human chain, interviewees were asked to discuss their experiences. One respondent recalls:

Each university or hospital or town would have some sort of Sajūdis people. This group had some sort of leader and people would go to meetings. The institutions would send leaders to visit other groups, and at the Kaunas level the group would be given instruction as to what would happen later on. Automatically, the leaders would go from a local level to the national level meetings, and discuss things there at a national level (female participant A, Kaunas, Lithuania; aged 15-20 in 1989).

Petersen notes that rural villages within close proximity in any given region may exhibit different patterns of rebellion. ${ }^{25}$ The format of collaboration between local groups of dissenters and national groups arguably reduced this risk, and consolidated confidence in participation levels. The dissemination of information reduced the potential for pockets of resistance to widespread protest to grow. By ensuring that regional or local channels of organisational and management structures were established, a sense of individual

${ }^{23}$ V.S. Vardys, J.B. Sedaitis, Lithuania: The Rebel Nation (Boulder, 1997), p. 106.

${ }^{24}$ M.R. Beissinger, 'The Intersection of Ethnic Nationalism and People. Power Tactics in the Baltic States, 1987-1991', Civil Resistance and Power Politics: The Experience of Non-violent Action from Gandhi to the Present, eds. A. Roberts, T. Garton Ash (Oxford, 2011), p. 234.

${ }^{25}$ Petersen, Resistance and Rebellion, p. 10. 
ownership of rebellion reduced the possibility of disengagement or ambivalence in both urban and outlying areas. Individuals remained closely engaged with the protest, and simultaneously advanced wider nationalist objectives. The conceptualised metaphor of the human chain as a single entity made up of smaller component parts was expressed. It was stated:

In every town they had their groups, so at all times the chain was like one unit. In order to make sure there were no breaks in the chain, everyone had their specific tasks ... to go to some place in Lithuania to fill in some space that was left (female participant F, Kaunas, Lithuania; aged 15-20 in 1989).

Some commentators have considered the role of existing network strategies, established during the Soviet period, in facilitating openings for national movements to exploit across much of Eastern Europe. Corruption of such networks encouraged cooperation established between local groups in each country to be adopted as a wider strategy at a transnational level. Building upon interstate networks established during the Soviet period, such as the 'Friendship Cities', and strengthening historic ties such as the interwar 'Latvian-Lithuanian Friendship Alliance' and 'Latvian Lithuanian Association', the countries of the Baltic States were united in a common objective. ${ }^{26}$ A Popular Front leader who played a key role in orchestrating the Latvian tranche of the protest explained:

There was a lot of communication between the different groups, as this was necessary. There was a feeling that this Baltic Chain belonged to all the peoples of the Baltic countries. We had official contact with groups in Estonia and Lithuania. Without building these friendships, it would have been practically impossible to put in place all the ideas that were coming at that time (male participant $\mathrm{K}$, provincial town, Latvia; aged 30-45 in 1989).

Official networks which had been established by the Soviet hierarchy facilitated planning meetings between the hierarchies of the national movements, particularly within Latvia and Lithuania. It was established that:

Lithuania had many Friendship Cities, as we used to visit towns there. Estonia didn't work so well. Perhaps it was too far. I still have at home some brochures or leaflets about the events. Really, these friendship cities had been established and were funded by the Soviet time. These networks were already in place (male participant K, provincial town, Latvia; aged 30-45 in 1989).

26 J. Škapars, The Baltic Way to Freedom: Non-violent Struggle of the Baltic States in a Global Context (Riga, 2005), p. 464. 
It was also found that religious networks, which had remained largely underground during the Soviet period, utilised their internal networks to help communicate across different regions, thus facilitating the Baltic Chain protest. It is suggested that the influence of religion played a part within organisational structures resulting from a localised organisational force which has the ability to create and maintain attitudes. ${ }^{27}$ For many of the respondents, the role of religion, notably the Catholic Church in Lithuania and the Lutheran Church in Latvia, had provided a Soviet-era framework for dissent, which later facilitated the organisation of protest. Early examples of resistance against the Soviet regime was evident in Latvia, with the establishment of a 'clergyman's group' which cut all ties with the KGB and refused to hold services to celebrate Soviet holidays. ${ }^{28}$ In Lithuania, the Catholic Church, although isolated from Western Catholicism, "stayed close to the people and identified with the population's spiritual, social and national needs'. ${ }^{29}$ One Catholic respondent, whose father assisted dissident activities, describes how he used religion to protest. She stated:

His expression of protest against Soviet expression would be his religion. It was almost an open statement to be actively involved in some radical movement, and he would make open statements that perhaps he couldn't work on this day, or that day because it was a religious holiday (female participant B, Kaunas, Lithuania; aged $30-45$ in 1989).

These religious networks were not only fundamental in establishing patterns of resistance against the Soviet regime, but would also cultivate networks of communication. An example is provided by one Latvian nationalist activist who was a member of the Lutheran Church. He remembers having:

a very good relationship with the pastor. It was our pastor who consecrated the Latvian flag. During his sermons it could be described as perhaps information was distributed (male participant K, provincial town, Latvia; aged 30-45 in 1989).

Information was also distributed in written form during the Soviet period within religious networks, and it is argued that the Lithuanian independence movement Sajūdis looked to the Catholic Church and to the publication of 'The Church Chronicles' as a template for establishing later communicative networks used within the

27 Petersen, Resistance and Rebellion, p. 48.

28 Škapars, The Baltic Way to Freedom, p. 455.

${ }^{29}$ Vardys, Sedaitis, Lithuania, p. 116. 
organisation of the Baltic Chain. On discussing the impact religion played in Lithuania, one interviewee stated that:

It helped the future development of Sajūdis. They would see how the Church could publish these chronicles and look to how they were not caught by the government. The Sajūdis movement could understand the power of this free word, so in a way it stood as an example for their future works (male participant L, Kaunas, Lithuania; aged 15-20 in 1989).

As can be shown in the following section, the practice and distribution of Church-produced leaflets and pamphlets, which were being copied and recopied during the Soviet period, re-emerged within later examples of media distribution.

\section{Media influence}

In considering the flow of information to participants of different backgrounds and within different regions of Lithuania and Latvia, an examination of those structures which facilitated this dissemination was required. With claims that Gorbachev's policy of glasnost resulted in changes within political opportunity structures, ${ }^{30}$ respondents were questioned on the role of mass media channels in orchestrating the protest. From interview responses, it was clear that the liberalisation of press structures and the development of programming in the titular language around the introduction of glasnost were central to the flow of information throughout Lithuania and Latvia during the period of Awakening. From 1987 onwards, titular language broadcasts with a nationalist content were widely accessible, and access to foreign media outlets such as Radio Free Europe, Radio Freedom and Voice of America were no longer blocked by central government. The dissemination of information as noted by Bessinger meant that civil protest was no longer 'spatially confined, but followed the lines of information flow'. ${ }^{31}$

Respondents were asked to discuss the mediums which provided the main channels of communication in the build-up to the Baltic Chain protest. A review of secondary sources, obtained including radio transcripts and press clippings, highlights the importance of the media in generating information flows. The 'Homeland' newspaper supplement from Estonia provided instructions relating to the protest in July and August 1989. It was stated:

${ }^{30}$ Gorenbug, 'Ethnic Mobilization', p. 198.

${ }^{31}$ Beissinger, 'The Intersection of Ethnic Nationalism and People', p. 240. 
To mark the 50th anniversary of the Molotov-Ribbentrop Pact on August 23rd, it has been proposed to light on this day candles at home and abroad and form an uninterrupted human chain throughout the three occupied states. This should be done simultaneously everywhere at $7 \mathrm{pm}$ Estonian time or 9am Californian time ... Called 'The Baltic Way', the action should symbolise the determination and striving for sovereignty of the three Baltic Nations. ${ }^{32}$

Additional declarations on the annexation of the Baltic States were published by 'Homeland' on 23 August with the rallying call:

We have searched for a solution, and we have called our solution the BALTIC WAY. The BALTIC WAY is a parliamentary way for the peaceful estuation of our statehood. The BALTIC WAY does not represent a threat to anyone. The BALTIC WAY will guarantee social security, civil rights and economic progress to all the people in the Baltic republics regardless of their nationality. The BALTIC WAY is a way to democracy. The BALTIC WAY is the only way to freedom, brotherhood and equality on the shores of our common Baltic Sea. ${ }^{33}$

An article by Juris Dreifelds states that radio services provided by Radio Free Europe and Radio Liberty had an audience of around $20 \%$ of the population of the Baltic States prior to 1987 , and that in subsequent years 'this radio service became the main communications tool for many more demonstrations, meetings, discourses, historical revelations and speeches by prominent leaders'. ${ }^{34}$ Despite international mediums such as Radio Free Europe or Voice of America being widely accessible in 1989, it was found that respondents placed greater emphasis on the importance of nationally produced television and radio broadcasts as compared to Western-based media outlets. One Lithuanian respondent noted that:

I definitely remember the Voice of America, but there was enough information in the Lithuanian media, like television, radio and newspapers (female participant B, Kaunas, Lithuania; aged 30-45 in 1989).

This sentiment was echoed by another participant, who explained that television in the titular language played a central role in gathering information and in organising the protest. When discussing events leading up to protest, she stated:

I think that everyone knew about it. It was something very public. I think we heard a lot about it on the radio and TV. At that time, we had good Lithuanian TV that we could watch (female participant B, Kaunas, Lithuania; aged 30-45 in 1989).

32 Homeland, supplement to the Estonian KODUMAA weekly, 30(239), July 26, 1989.

33 Ibid., 34(243), Aug 23, 1989.

${ }^{34}$ J. Dreifelds, Latvia in Transition (Cambridge, New York, 1996); Škapars, The Baltic Way to Freedom, pp. 8-379. 
As a result of the implementation of glasnost, it would appear that Western mediums were becoming secondary in importance to expanding national broadcasts within both Lithuania and Latvia. This resulted from nationalist movements becoming more actively engaged in establishing the content of broadcasts and publications. Extracts taken from a discussion panel of Latvian activists highlights that 'many of those who worked for the media switched sides and began to use the Communist Party media for other purposes'. ${ }^{35}$ This theme was raised with a media specialist in Riga. In her view, existing Soviet media sources were manipulated by nationalist sympathisers to provide a channel of information supporting civil protests. Another respondent discussed the Soviet Youth publication Padomju Juanatne and its editor, who, although a Party member, was 'nationally orientated'. Gorbachev's reforms allowed space for an element of plurality, as a limited degree of free speech was tolerated in so far as socialist values would not be denied or challenged. ${ }^{36}$ Padomju Juanatne therefore remained loyal to the Communist Party due to its status as an officially sanctioned newspaper, yet introduced distinct changes in editorial content. In Lithuania, Algimantas Čekuolis, having taken over a weekly propaganda publication aimed at those overseas, changed the tone with 'unflinching exposures of the system's sins and bold political demands'. ${ }^{37}$

With many members of the emerging nationalist movements employed within key media positions, there was little resistance to the new tone of publications and broadcasts. Describing events prior to the protest of August 1989, a former Latvian National Front activist discussed the position of sympathetic media workers. He recalls that:

The National Front had practically taken over the power in the state, and the official structures knew that, so there was practically no problem in publishing any article in the newspaper. It was also being announced on the TV that the Baltic Chain was being organised and would be happening (male participant $\mathrm{K}$, provincial town, Latvia; aged 30-45 in 1989).

Newspapers and pamphlets were arguably the most vital resource in helping to organise the event, with the proliferation of local publications running parallel to the expansion of locally organised

${ }^{35}$ The panel discussion, in: Regaining Independence: Non-violent Resistance in Latvia 1945-1991, eds. V. Blūzma, T. Jundzis, J. Riekstins et. al.

${ }^{36}$ Ibid., p. 290.

${ }^{37}$ Vardys, Sedaitis, Lithuania, p. 98. 
nationalist political sources. As had happened in other regions elsewhere, also under Moscow's control, it became imperative for public confidence in the nationalist agenda to create what Pfaff describes as a 'second public sphere', which challenged official channels and stimulated fresh debate. ${ }^{38}$ Whilst the advent of glasnost had provided a legal basis for the galvanisation of the nationalist message within the media, elements of distrust of official sources remained. This distrust centred on television broadcasts to a greater extent than on newspapers, with one respondent noting that:

I think though that the TV was somehow filtered. I believe that the main means of communication were the newspapers. Newspapers were the most important specifically the Sajūdis newspapers. There were lots of different organisations publishing newspapers, for example the Democratic Party, the Green movement, but mostly it was the Sajūdis news that was key for people (female participant F, Kaunas, Lithuania; aged 15-20 in 1989).

It was also felt by journalists working within Lithuania and Latvia that the relaxation of the regulatory structures within the media following glasnost was to be viewed with suspicion. One journalist highlights the feeling of many, suggesting that:

There were some programmes that would go out in ' 87 that were given to the media to maybe test the limits. People had theories that maybe this was the KGB testing the water (male participant H, Riga, Latvia; aged 30-45 in 1989).

To challenge such distrust and to ensure that 'successful collective action can make future collective actions an attractive proposition for potential participants', ${ }^{39}$ the strategy of disseminating trusted sources of information, including locally produced newspapers and pamphlets, was employed. The formation of small local political units advancing the nationalist message in towns and villages aided the organisational process and encouraged widespread participation by nurturing close and trustworthy networks. By establishing and distributing locally produced newspapers, trusted and well-known members of the community ensured that the information required was widely distributed and bolstered individuals' confidence in the event. Furthermore, this pattern of exit behaviour correlated with a strong desire for news consumption during the period. It was stated by one participant that:

38 Pfaff, Exit-voice Dynamics and the Collapse of East Germany, p. 91.

39 Eglitis, Imagining the Nation, p. 32. 
People of that time not only used media as we do today, but they loved media. Media at that time served the function of a leader. People were waiting for their daily newspapers to organise their day - to understand what they have to do (female participant D, Riga, Latvia; aged 15-20 in 1989).

The circulation of local newspapers was in some instances greater than that of mainstream publications. Newly emerging media sources also began to replace the dictatorial style of the Soviet media system, with Blūzma noting that the increasing number of publications which did not pass through the State Censor's Office 'proved to be important in stirring the general public into action'. ${ }^{40}$ Circulation figures of one locally produced nationalist newspaper, brought to the interview by a local activist, showed that around 7,000 copies were distributed within a town of around 19,000 people. This was equivalent to one publication received by almost every household. The interviewee described the distribution of political newspapers in his town and around workplaces. It was stated that there was:

... an agreement with the local post office, and maybe it [the publication] didn't go in every mailbox, but could also just be left lying around (male participant $\mathrm{K}$, provincial town, Latvia; aged 30-45 in 1989).

Nationalist publications often also reached those serving on military service far away from local distributors. One particular interviewee discussed the ways in which family members could circulate news and information to military barracks without the fear of reprisal in 1989. Support from the Russian-speaking community was evidenced with one account given by an interviewee. He recalls:

Sometimes there was a big military airfield and there were Russian military and wives, maybe some teachers. These women would distribute the newspaper of the National Front also, and this would be spread between the military garrisons, but of course it would be in Russian (male participant L, Kaunas, Lithuania; aged 15-20 in 1989).

As identified by some scholars, it could not be assumed that all of those who identified with the pro-independence movements were from the titular communities, as a substantial number were Russian speakers who also supported the independence initiatives. ${ }^{41}$

Despite a display of intent to protest from the nationalist movements of the Baltic States appearing within publications, it was only after the event that condemnation from the Soviet officials became

${ }^{40}$ Regaining Independence, p. 295.

${ }^{41}$ Eglitis, Ardava, 'The Politics of Memory', p. 1041. 
apparent. A Lithuanian interviewee, on National Service in the Soviet army at the time of the protest, described the mood change within the barracks on 23 August 1989. Initially he observed that:

The Soviets - they were afraid a lot because they couldn't predict what would happen. The soldiers from the Baltic States, they would know a lot of information - a lot of what was going on (male participant L, Kaunas, Lithuania; aged 15-20 in 1989).

With an increasing awareness of the visual impact that this largescale and symbolic public protest would create within the media, Soviet officials ordered a forcible clampdown on media output immediately after the event. Soldiers were ordered by officials to watch only news sanctioned by the Party, with one participant recalling:

There was a special TV programme on the Soviet Channel - on the news - the national channel. We were ordered to sit and listen to the news - really we were forced to go, and we were supervised by military officials to listen to the news. On this news, the Baltic Chain was condemned (male participant L, Kaunas, Lithuania; aged 15-20 in 1989).

This response suggests that Soviet officials hugely underestimated both the power of rapidly expanding media channels as conduits for information and organisation for national movements, and also the scale of the protest. Recalling the events of 23 August 1989, Vytautas Landsbergis describes the reaction to the Baltic Chain from Moscow as 'surly and resentful', with Soviet media outlets moving quickly to denounce protesters as extremists leading 'the Baltic nations towards an abyss'. ${ }^{42}$ As noted by Senn, Moscow television news read a declaration charging that 'nationalist extremist groups' had 'misappropriated the role of the true proponents of national affairs', and that some of the 'mass information media' had joined them in this 'unhealthy' development. ${ }^{43}$ Despite this condemnation, the media continued to play a role, with international news outlets picking up the story and bringing the images of the protest to a global audience, thereby contributing to the inevitable departure of the Baltic republics from the Soviet Union.

\section{Experiences of conflict and areas of convergence}

Within the dominant narrative of the protest, the experiences of those who participated in the Baltic Chain are presented as a homogeneous display of dissent culminating from increasing occurrences of

${ }^{42}$ Landsbergis, Lithuania, Independent Again, p. 152.

${ }^{43}$ A.E. Senn, Gorbachev's Failure in Lithuania (New York, 1995), p. 67. 
smaller-scale protests. However, it is noted that 'variations exist in the types of roles that individuals come to play during sustained rebellion'. ${ }^{44}$ It is therefore reasonable to consider that participants' experiences differed, and that areas of internalised and externalised conflict could be identified. This section addresses these themes, and has sought to establish areas of conflict within particular social groups amalgamated under the auspices of a shared common goal. Interviews conducted explored whether variations occurred within communities and families of those who participated in the Baltic Chain. Interviewees were questioned on their knowledge of the protest, their level of engagement with the protest, and on any conflict or areas of divergence from the dominant and largely commemorative narrative surrounding the event.

On reflecting upon the nationalist developments of the late 1980s within Latvia, it is noted that 'people, especially the younger generation, tend to believe that there was a total unanimity and unbelievable harmony during the years of the Awakening ... that is a myth'. ${ }^{45}$ One apparent factor which seemed to reinforce this lack of cohesion has been identified, namely a notable generational divide within participant experiences. Petersen has argued that the younger generation are less constrained than other groups in relation to rebellion and protest, they are 'status conscious' and free of family and business commitments. ${ }^{46}$ From the interviews conducted, it was found that there was indeed a general absence of fear surrounding the protest, particularly amongst the younger generation. Participants who were aged between 18 and 40 at the time of the protest provided responses which included:

We didn't feel much threat from anyone anymore (female participant F, Kaunas, Lithuania; aged 15-20 in 1989).

We believed in the event. I don't think I thought about safety, and I was going with two children (female participant B, Kaunas, Lithuania; aged 30-45 in 1989).

It was widely expressed that the Baltic Chain was driven forward by younger people who had grown up during the period of "national communism' experienced from 1956-1968. The legalisation of nationalist groups resulting from reforms introduced under perestroika encouraged feelings of security in engaging with the nationalist cause of the later period. It was stated that:

${ }^{44}$ Petersen, Resistance and Rebellion, p. 8.

45 Škapars, The Baltic Way to Freedom, p. 135.

${ }^{46}$ Petersen, Resistance and Rebellion, p. 48. 
At the time there was no fear. The Baltic Chain was one of the last steps to the declaration on independence ... and remember ... Sajūdis was already a legal movement (male participant L, Kaunas, Lithuania; aged 15-20 in 1989).

With a realisation that Eastern Europe was lagging economically behind the West, and with the publication of the secret protocols of the Molotov-Ribbentrop Pact, 'the general feeling of national oppression was passed on to the younger generation'. ${ }^{47}$ This may account for higher levels of engagement among younger people, with one respondent explaining that:

My parents felt like they were a broken generation. They were 30 or 40 years old. I think that the people who were participating in the Baltic Chain were mainly 30-45 or something like that. They were a lost generation, and this was the energy that was driving them (female participant C, Kaunas, Lithuania; aged 15-20 in 1989).

The protest movement, being invigorated with the disillusionment of the younger generation, also witnessed resistance from older participants. A factor in this generational divergence of participant experience can be attributed to the influence of memory affecting those who had lived for a more sustained period of Soviet rule. For these older participants, memories of deportations, imprisonment or torture remained fresh. Davoliūte explores the tensions between the differing age groups in postwar Lithuania, and notes that 'two people with basically the same background would often find it difficult to understand or relate to one another if they were separated by more than a few years of age' ${ }^{48}$ Additionally, younger participants suggested that concerns of a more pragmatic level existed within the older generation, who had qualms that participation in the protest could lead to a loss of status or opportunity. Such fears commonly arise in a totalitarian regime, as it is claimed that this system creates 'a climate of diffused fear which is linked to communication, inhibition, individualisation and social isolation'. ${ }^{49}$ Responses expressed included:

Older people ... they were kind of reserved. They had their own experiences of war, and they were afraid (female participant B, Kaunas, Lithuania; aged 30- in 1989). At this time it was still Soviet, so you still had to be careful about speaking to people (female participant C, Kaunas, Lithuania; aged 15-20 in 1989).

${ }^{47}$ O. Nórgaard, The Baltic States after Independence (Northampton, Mass., 1999), p. 36.

${ }^{48}$ V. Davoliūte, The Making and Breaking of Soviet Lithuania: Memory and Modernity in the Wake of War (London, New York, 2013), p. 78.

49 J.W. Pennebaker, D. Páez, B. Rimé, Collective Memory of Political Events: Social Psychological Perspectives (New York, 2013), p. 149. 
Whilst it was found that there was often reluctance among the older generation to participate, their reasons for disengagement may have led to a strengthening in the resolve of younger people to participate and engage with the protest. It was stated:

The families who lost people during the Soviet repressions were for sure participating in this event. It was important that this Baltic Chain took place. During the publicity of the Molotov-Ribbentrop Pact, specifically this thing united people and moved them emotionally. So if you had lost your grandparents or family this was important (female participant C, Kaunas, Lithuania; aged 15-20 in 1989).

Ideological differences and internal conflict relating to positions of power and status were evidently also problematic, most notably within older groups. Vytautas Landsbergis commented that 'there were obviously some who did not join us along the Baltic Way, and they included the bewildered local leaders of the Communist Party'. ${ }^{50}$ Support for the Communist Party and subsequent disengagement with the protest was seen as being advantageous for some in positions of power. One interviewee noted that his grandparents morally supported the protest; however, other relatives of the same generation were actively opposed to taking part. It was said:

The brothers and the families of my mother's brothers were pro-Communist because they had very good positions at that time. They were officials and held important positions in that system. So in one family there were different views (male participant L, Kaunas, Lithuania; aged 15-20 in 1989).

Another participant described the conflict within her family stating:

We went there by car, but we would never talk of this to my grandparents, who were living in another town maybe 200 kilometres away. They were somehow against it, because they believed in the Soviet ideals, and they didn't believe that everything was a lie. So we didn't tell them. We let them live in their own world, so conflict was solved as we didn't talk about it. You would listen to their views but you wouldn't contradict them, because you would respect their beliefs (female participant C, Kaunas, Lithuania; aged 15-20 in 1989).

A number of conflicts emerged within the various Popular Front movements who sought to pursue differing strategies in order to advance the nationalist cause. Discussing the formula for success, Jundzis states that 'arguments over the predominance of one or other strategy during the Awakening turned into serious political battles'. ${ }^{51}$ Personal and political animosities exhibited during the

${ }^{50}$ Landsbergis, Lithuania, Independent Again, p. 152.

51 Škapars, The Baltic Way to Freedom, p. 209. 
late 1980s are well documented; however, little element of this conflict has transferred into the dominant narrative of the Baltic Chain protest. Interviewees, many of whom were keen to emphasise the galvanisation of relationships as a result of participation in the protest, also acknowledged and encapsulated the ideological and personal conflicts that existed at the time. Those who participated in the protest often disagreed with particular factions, yet were able to put differences aside on the day. One participant recalls:

I can particularly remember the members of Sajūdis that assembled. Some of them were Leftists. My father was completely against this ideology - but you know - there were some people who had different actions to their words. But my father joined hands with these people. In other words, all ideological differences disappeared. People were together for this one cause (female participant B, Kaunas, Lithuania; aged 30-45 in 1989).

From the interviews conducted, the generational divide was found to be the main source of conflict. Youth and student groups were credited with organising visible public events as a sign of resistance to Soviet rule prior to the Baltic Chain protest. Controversy surrounded a public exhibition of 1987 during which students from the Art Academy in Riga encased their heads and torsos in cages in direct defiance of the repression of the Soviet regime ${ }^{52}$. In Lithuania, Sajūdis had begun to realise the potential for mass demonstrations, with one such event protesting against the destruction of historical monuments in Trakai. Senn notes that 'according to Juozaitis this demonstration was the work of the youth in the Initiative Group'. ${ }^{53}$ Young people were also actively involved in placing rock and punk music within the mainstream in order to advance the nationalist message. Rock marches, rock concerts and public rallies utilised space created by government reforms to disseminate a political message. However, fears over political expression remained prevalent within the older generation, with one respondent recalling:

I remember a guy next door, a neighbour, and he was a 'hippy', a punk. Of course, the term 'hippy' in English is much different. Perhaps it is an insult or something. But this guy was in a rock or metal band, and I remember that my parents did not want me to go there or have anything to do with him, because he was of course political to be in this band (female participant A, Kaunas, Lithuania; aged 15-20 in 1989).

${ }^{52}$ D.S. Eglitis, Imagining the Nation, p. 27.

${ }^{53}$ A.E. Senn, Lithuania Awakening (Berkeley, Los Angeles, Oxford, 1990), p. 78. 
Musical events and gatherings organised by young people became a medium for uniting groups of different ages and backgrounds. One musician stated that:

Different people would come. You would see old age pensioners who were like hard-core Catholics among all those metal bands, and that was weird. The whole audience after the concert would sing the national anthem together. So, of course, it was close. Those people, those rock people, were using music as a medium, and as a way of connecting people (male participant J, Kaunas, Lithuania; aged $15-20$ in 1989).

Despite a strong nationalist message being portrayed at these events, caution and compromise were again exercised. It was stated:

Basically, when I remember our own lyrics, we were more individualistic, maybe describing how we were uncomfortable in the system and situations, but we were not saying that you should shoot Gorbachev (male participant J, Kaunas, Lithuania aged 15-20 in 1989).

Interaction within the music scene was also used to relay information between groups, and utilised both formal and informal networks. Gorenburg suggests that 'the denser the social networks and the closer the social ties linking members of a particular community, the faster it was for movement activism to spread among the group'. ${ }^{54}$ This is true for youth groups who would use friendship networks and Soviet meeting spaces in order to share information. One participant recalls:

The people from the sub-cultures hanging out in the city would get information from there. You would tell this to your classmates, and so this was sort of wordof-mouth, I suppose. There was an ecological club. People would be hanging out with people of other sub-cultures. And you would be going to concerts, but at the same time you would be going to the ecological club. So we were much closer to the politics (male participant J, Kaunas, Lithuania; aged 15-20 in 1989).

Other channels where information was distributed within community and social groups included the scout or Ateitininkai movement. Contact between Sajūdis and the Scout Association was used to organise the assembly point in the chain for some young people. It was remembered by one member that officials would come to the scout meetings to talk to scout leaders in the run-up to the protest. It was recalled that the scout group,

... would of course be responsible for organising us a place to stand, so they must have spoken with someone. I remember that this is how we were organised. I organised everything with the Ateitininkai. So I was part of the organisation at that

${ }^{54}$ Gorenbug, 'Ethnic Mobilization', p. 205. 
time, and that's how I went to the place I went to stand in on that route (female participant A, Kaunas, Lithuania; aged 15-20 in 1989).

At the time of the Baltic Chain protest, nationalist organisations were emphasising the benefits of cooperation and communication, not only between titular communities, but also between different ethnic groups, as noted by Lieven. Nationalist demands were presented as a 'struggle for popular rule, economic prosperity and social justice for all nationalities'. ${ }^{55}$ Despite evidence of the convergence of both communities in the struggle for independence, one Latvian Popular Front activist, responsible for coordinating the protest from his local region, recounted areas of external tension on the day of the event. He states:

Yes, there was always some sort of conflict at that time. The Pioneers, some leaders of the Interfront were always agitating against the National Front. It was even true that the deputy of our local police had a conversation with someone where he said that the National Front was a joke. I had planned to be there maybe two hours before the start, but this day proved difficult as we were stopped by the road police of the Interfront movement. These Interfront had instructions to block the cars that were coming and to only speak Russian. This was happening even on the main road. Even with help from the police we could not pass through the blockade. The Baltic Chain was one of the last events I organised, and it was almost unsuccessful due to the problems with the Interfront. I had to organise the inspector of traffic police to accompany the column with lights (male participant $\mathrm{K}$, provincial town, Latvia; aged $30-45$ in 1989).

Internalised conflicts and concerns over participating were much reduced where positive emotional connections to the protest existed. Many of the interviewees provided responses which mirrored the rhetoric of the existing commemorative literature surrounding the protest. For many participants, the influence of family and friends participating alongside created a safe and welcoming environment in which to express their resistance to the Soviet regime. Responses given included:

My family also participated, my father, my mother, and me. I have spoken with them of their emotions that day, and they would say that the whole of Lithuania was energetically charged at that time. It was like one whole organism (female participant C, Kaunas, Lithuania; aged 15-20 in 1989).

And:

The feeling I remember was very tearful, very emotional. It was a great festival. We made a huge bonfire and had a barbeque. It was something very special (female participant A, Kaunas, Lithuania; aged 15-20 in 1989).

55 A. Lieven, The Baltic Revolution: Estonia, Latvia, Lithuania and the Path to Independence (New Haven, London, 1994), p. 302. 
Conversely, where family or peer influence was found to be reticent concerning the protest, individual levels of engagement dropped. This challenges the much-cited rhetoric suggesting that there was a sense of homogeneous participation and identification with the protest. In any rebellion, Petersen notes that 'there are collaborators, neutrals, locally based rebels, mobile fighters and gradients in between'. ${ }^{56}$ Some families adopted a pragmatic approach, with one respondent recalling:

Nobody in my family was very eager about it. They were somehow very calm, and they thought - ok, so it will be this way, or so it will be that way - but nobody was crazy about going (female participant D, Riga, Latvia; aged 15-20 in 1989).

Another interviewee, who lived alone and who had recently been separated from her family and friends following a move to Riga for work, stated that:

Yes I went, but I'm not really sure why. I was having a day off, so I was in bed. And of course it was on the radio, so maybe I felt like I should go. I hadn't planned to do this, to go, but somehow on the day I thought I would go there (female participant E, Riga, Latvia; aged 15-20 in 1989).

Such examples of reticence challenge the existing discourse of the protest, with much of the existing literature largely ignoring the individual realities of both those who chose to participate, and those who did not. It was clear from the interviews that a number of variables impacted on levels on engagement, and on the orchestration of the event.

\section{Conclusions}

The aim of this article has been to provide an alternative lens though which to view the Baltic Chain protest of 23 August 1989. In highlighting the views and experiences of a sample of those who were involved in some way with the protest, this micro-level assessment moves firmly away from existing top-down commemorative accounts. The grass-roots approach adopted has led to a challenge of particular elements of existing rhetoric, such as the homogeneous nature of engagement, and has encapsulated the insights of individuals on the ground, often lost within the elite-produced official narratives. It is believed that this work offers a foundation for further research, and encourages a deeper understanding of the events surrounding the Baltic Chain protest.

\footnotetext{
56 Petersen, Resistance and Rebellion, p. 8.
} 
It is concluded that informal networks, which were established during the Soviet period, played an important role in procuring physical resources and in establishing trusted relationships which helped to facilitate the protest. Informal networks of exchange, combined with officially created and subsequently corrupted networks, advanced the nationalist message and encouraged wide-scale protest. Religious organisations were also found to encourage levels of participation, and to establish alternative channels of communication.

The liberalisation of the media as a result of glasnost was central to the spread of information throughout Lithuania and Latvia, and greatly impacted upon the ability of organisers to disseminate information, both to titular groups and to members of the Russian-speaking community. Western media sources became less popular, and were considered to be secondary in importance to expanding national broadcasts and publications. Locally produced pamphlets and publications were widely available, and were often exchanged within families and communities, thus spreading vital information on events surrounding the protest.

Perhaps the most interesting findings relate to issues of conflict identified within the sample group, which contradicts the dominant commemorative narrative. Where existing portrayals of the Baltic Chain protest emphasise a homogeneously embraced event, this work has identified and highlighted a clear divergence in participant experience. Generational cleavages were apparent in levels of support for the protest, and some reticence and indeed resistance was expressed towards the event. However, it was found that the coordination and organisation of the protest drew from a variety of individuals from differing backgrounds, and relied upon a range of non-elite and corrupted official structures in order to orchestrate the event.

\section{Author Details}

Paula Christie is a $\mathrm{PhD}$ research scholar in Central and East European Studies (University of Glasgow), and a teaching assistant in social sciences at the School of Social and Political Sciences of the College of Social Sciences of the University of Glasgow.

Address: Central and East European Studies, University of Glasgow, Lilybank House, 42 Bute Gardens, Glasgow G12 8RS, UK

E-mail: p.christie.1@research.gla.ac.uk 


\section{References}

BEISSINGER, M.R. 'The intersection of Ethnic Nationalism and People. Power Tactics in the Baltic States, 1987-1991', in: A. Roberts and T. Garton Ash (eds.), Civil resistance and power politics: The Experience of Non-violent Action from Gandhi to the Present (Oxford, 2011), pp. 231-246.

BLŪZMA, V., JUNDZIS, T., RIEKSTINS, J. et. al (eds.), Regaining Independence: Non-violent Resistance in Latvia 1945-1991 (Riga, 2009).

DAVOLIŪTE, V. The Making and Breaking of Soviet Lithuania: Memory and Modernity in the Wake of War (London, New York, 2013).

DELLA PORTA, D., KEATING, K. Approaches and Methodologies in The Social Sciences: A Plualist Perspective (Cambridge, New York, 2008).

DREIFELDS, J. Latvia in transition (Cambridge, New York, 1996).

EGLITIS, D.S. Imagining the Nation: History, Modernity, and Revolution in Latvia (University Park, PA, 2002).

EGLITIS, D.S., ARDAVA, L. 'The Politics of Memory: Remembering the Baltic Way 20 Years after 1989' Europe-Asia Studies, 64(6) (2012), pp. 1033-1059.

GORENBUG, D. 'Ethnic mobilization', in: O. Protsyk; B. Harzl B. (eds.) Managing Ethnic Diversity in Russia (London, New York: 2013), pp. 191-214.

HOMELAND, supplement to the Estonian KODUMAA weekly (1989).

KOZLOV, V.A., MACKINNON, E.M. Mass Uprisings in the USSR: Protest and Rebellion in the post-Stalin Years (Armonk, NY, 2002).

LANDSBERGIS, V. Lithuania, Independent Again: The Autobiography of Vytautas Landsbergis (Cardiff, 2000).

LEDENEVA, A.V. Russia's Economy of Favours: Blat, Networking and Informal Exchange (Cambridge, UK, New York, NY, 1998).

LIEVEN, A. The Baltic Revolution: Estonia, Latvia, Lithuania and the Path to Independence (New Haven, London, 1994).

MISIUNAS, R.J., TAAGEPERA, R. 'The Baltic States: Years of Dependence, 1980-1986', Journal of Baltic Studies, 20(1) (1989), pp. 65-88.

MISIUNAS, R.J., TAAGEPERA, R. The Baltic States: Years of Dependence, 1940-1980 (London, 1983).

MUIZNIEKS, N.R. 'The Influence of the Baltic Popular Movements on the Process of Soviet Disintegration', Europe-Asia Studies, 47(1) (1995), pp. 3-25.

NǾRGAARD, O. The Baltic States after Independence (Northampton, Mass., 1999).

OBERSCHALL, A. Social Conflict and Social Movements (Englewood Cliffs., N.J., 1973).

PENNEBAKER, J.W., PÁEZ, D., RIMÉ, B. Collective memory of Political Events: Social Psychological Perspectives (New York, 2013). 
PETERSEN, R.D. Resistance and Rebellion: Lessons from Eastern Europe (Cambridge, New York, 2001)

PFAFF, S. Exit-voice Dynamics and the Collapse of East Germany: the Crisis of Leninism and the Revolution of 1989 (Durham, N.C., 2006).

PRZEWORSKI, A. Democracy and the Market: Political and Economic Reforms in Eastern Europe and Latin America (Cambridge, New York, 1991).

SENN, A.E. Lithuania Awakening (Berkeley, Los Angeles, Oxford, 1990).

SENN, A.E. Gorbachev's Failure in Lithuania (New York, 1995).

ŠKAPARS, J. The Baltic Way to Freedom: Non-violent Struggle of the Baltic States in a Global Context (Riga, 2005).

ŠMIDCHENS, G. 'National Heroic Narratives in the Baltics as a Source for Nonviolent Political Action', Slavic Review. 66(3) (2007), pp. 484-508.

SMITH, D. J., PABRIKS, A., PURS, A., LANE, T. The Baltic States, Estonia, Latvia and Lithuania (London, New York, 2002).

SMITHEY, L., KURTZ, L.R. "“We Have Bare Hands” Nonviolent Social Movements in the Soviet Block', in: S. Zunes; S. Beth Asher; L. Kurtz (eds.), Nonviolent Social Movements: A Geographical Perspective (Malden, MA, 1999), pp. 96-124.

TILLY, C., TARROW, S. Contentious Politics (Colorado, 2007).

ULFELDER, J. 'Baltic Protest in the Gorbachev Era: Movement content and dynamics, The Global Review of Ethnopolitics. 3(3-4) (2004), pp. 23-43.

VARDYS, V.S., SEDAITIS, J.B. Lithuania: The Rebel Nation (Boulder, 1997). 


\section{BALTIJOS KELIAS: MIKROPERSPEKTYVINIS DIDELĖS APIMTIES PROTESTO ORGANIZACINIO ASPEKTO TYRIMAS}

Santrauka

\section{PAULA CHRISTIE}

Kaip žinoma, viena iš M. Gorbačiovo vykdytos glasnost' politikos išdavų buvo slaptujų Molotovo-Ribentropo protokolų išviešinimas. Tai sukèlè Sovietų įvykdytos Baltijos šalių okupacijos pasmerkimą, kurio kulminacija buvo Baltijos Kelio protestas - vienos didžiausių žinomų žmonių grandinių sudarymas. Kaip buvo suorganizuotas ir koordinuotas šis renginys, įtraukęs beveik du milijonus gyventojų ir nusitęsęs 671 kilometrą per Lietuvą, Latviją ir Estiją? Ar protesto akcijos dalyvių įsitraukimui ir patirtims individualiame lygmenyje turejo itakos specifiniai kintamieji kriterijai? Straipsnyje analizuojamos patirtys tų, kurie į ši protestą buvo įsitraukę jo žemiausiu (grassroot) lygmeniu ir todèl leidžia susidaryti kiek detalesnį dalyvavimo bei motyvacijos paveikslą, kurio neretai trūksta dominuojančiuose ịvykio naratyvuose.

Tyrimas atskleidè, jog Sovietiniu laikotarpiu suformuoti neformalūs komunikacijos tinklai protesto akciją organizuojant vaidino svarbų vaidmenį: padejjo ieškoti materialinių resursų bei sukurti tarpusavio pasitikejjimu grịstus santykius. Neoficialus tarpusavio bendravimas kartu su oficialiais korumpuotais tinklais leido platinti tautinę informaciją, o tai skatino plataus masto protestą. Religinès organizacijos taip pat palaikè dalyvavimą protesto akcijoje ir kartu kūrè alternatyvius komunikacijos kanalus.

Vienas įdomiausių tyrimo rezultatų - jo nehomogeniškumo apraiškos, kas prieštarauja dominuojančiai oficialiajai nuomonei. Matyti, jog i protesto akciją reaguota nevienodai, būta nuomonių skirtumų, kurie ypač atsiskleidžia skirtingoms to meto kartoms atstovaujančių dalyvių pasakojimuose. Nepaisant to, ị Baltijos Kelio organizavimą įsitrauke ịvairių socialinių ir amžiaus grupių atstovai, galimai suvaidinę tam tikrą vaidmenį formuojant visuotinę visuomeninę akciją.

„Iniciatyvos iš apačios“ tyrimo strategijos pritaikymas leido suabejoti kai kuriais vyraujančios retorikos elementais, pavyzdžiui, homogeniška dalyvavimo forma, ir išryškino individualias patirtis, kurios dažniausiai neatsispindi elito konstruojamuose oficialiuosiuose naratyvuose. Tad tikètina, jog šis tyrimas galètų tapti pagrindu didesnei studijai. Jis skatina geriau pažinti Baltijos Kelio protesto akciją ir su ja susijusius įvykius. 